along was that the nuclear waste had heated and exploded thermally, or perhaps chemically. Especially during the first two years, nuclear wastes can heat up and possibly explode, unless they are carefully cooled. Medvedev notes that his theory, and a study published by the US Oak Ridge National Laboratory in 1980, conclude there was a single, major disaster on the basis of the ecological literature evidence that the Los Alamos report ignores.

The Los Alamos report asserts that the incident is relevant "in the light of the current nuclear waste disposal questions facing the United States" but does not explain just how. But it implies that even when nuclear wastes were disposed of in the sloppiest manner imaginable, they caused no single catastrophe. Deborah Shapley

\section{Britain in space}

\section{Up, up and away}

The British government, not usually enthusiastic about spending public money, seems keen to find the cash for a major national programme in remote sensing. Members of a "task force" who have spent the past six weeks working out the details, were putting the finishing touches to their report earlier this week.

Behind the government's enthusiasm is its wish to make the best use of the European Space Agency's (ESA's) Earth Resources Satellite (ERS1) to which it has already pledged $£ 28$ million, or 13 per cent of the cost. Britain does not seem to be the only country to find an interest in remote sensing. All ESA's 13 member states are expected to meet next week's deadline for pledging their contributions to the satellite, even though it will be built under ESA's optional applications programme.

Assuming that the money is forthcoming, ERS1 will be a preoperational ocean-monitoring satellite following along the lines of Seasat, the United States equivalent, which hinted at the usefulness of looking at the oceans in microwave before it went out of service after only three months.

Thus the three instruments that will make up the ERS1 payload - a synthetic aperture radar, a wind scatterometer and a radar altimeter - will all record in the microwave band. The satellite's low polar orbit will give it global coverage for measuring such variables as wind speed, wave height and polar ice cover. Data are expected to be of use to the scientific community, weather forecasters and shipping and offshore oil companies.

Britain's singular interest in ERS1 was stimulated last month when a team from the Science and Engineering Research Council's Rutherford Laboratory won a. competition to design a fourth instrument for the payload - an infrared scanning radiometer to measure sea-surface temperature to within half a degree Kelvin.
But the instrument, costing about $f 1$ million, must be built with British money.

If the general level of interest is anything to go by, however, the Rutherford team has little cause for anxiety. The "task force", which includes representatives from the Science and Engineering Research Council, the Natural Environment Research Council, the Meteorological Office, the Royal Aircraft Establishment at Farnborough, industry and the Department of Industry, has been drawing up plans for a far grander national remote sensing programme that. could involve spending more than $£ 4$ million. The report addresses three questions: the content of a programme of fundamental research into understanding microwave data; how to get the data to the user; and how to exploit commercially remote sensing in general.

The most costly consideration could be that of disseminating data from ERS1. ESA plans to set up a central ground receiving station at Kiruna in Sweden from which data can be relayed to agencies in individual nations. But the British study describes several options for a national ground station that could receive data directly from the satellite. These range from a $£ 4$ million station capable of receiving 120 megabits per second from the synthetic aperture radar to a much cheaper station capable of handling data at no more than 1 megabit per second. The cost would almost certainly have to be met by the industry department, which may try to persuade industry itself to chip in.

The data-handling part of the national programme could ride on the tide of the British government's general enthusiasm for information technology, so that it is no surprise that the report will be placed before Kenneth Baker, minister for information technology. The other important aspect for the government, however, is how to make money out of what is widely heralded as a growing international market. One option that the industry department is considering is to persuade private industry to set up a company to sell remote sensing data, as well as hardware and software for ground stations and satellite payloads.

The final details on the form of the national programme will probably take some months to work out. In the meantime, the plans seem to beg two questions. Are remote sensing data sufficiently attractive for potential users to pay for them? And is Britain, which has no national space agency, sufficiently well organized. On the first point, the industry department seems aware that it will be treading in the dark. But an earlier survey of more than 100 potential users has persuaded it that the risk could be worth taking, especially for ocean monitoring. And the civil servants who have been debating the merits of a national space agency for some time, could be encouraged by a decision to embark on a remote sensing programme.
Polish universities

Warsaw's rector

Poland's Council of Ministers has resumed consideration of two bills aimed at restructuring Polish higher education, apparently undismayed that the replacement of Dr Henry Samsonowicz as rector of Warsaw University is regarded in academic circles as a confirmation of growing fears for the future of scholarly life.

Dr Samsonowicz became rector in September 1980, under a compromise arrangement between the old system of government appointment of rectors and the promised reform by which the rector would be elected by the academic community. Subsequently, he was confirmed in office by a free election in which academics, students and university auxiliary staff were represented.

Since the imposition of martial law, Samsonowicz has been under increasing pressure and, according to some sources, was temporarily detained during the round-up of intellectuals in the first few days after the military take-over. A few weeks ago, he was expelled from the Polish United Workers' Party, since when his dismissal has been thought to be only a matter of time.

Nevertheless, the announcement that Dr Samsonowicz's "resignation had been accepted" caused a major wave of protests by Warsaw academics and students. At one point, all lectures were stopped in Warsaw University for 15 minutes to allow students and staff to sign protest letters.

The new rector, selected by the Minister of Science, Higher Education and Technology, is Professor Lazimierz Albin Dobrowolski, head of the department of zoology and ecology. In spite of the unfortunate circumstances of his appointment, Professor Dobrowolski does not seem as severe a hard-liner as some pessimists have assumed.

In a discussion on the proposed reforms of academic life in November 1980, he accepted as necessary the demands for reforms at all levels of education. He even implied that, theoretically, the universities already possess the right to make changes in their syllabuses which, if true, would make many of the reforms promised by the Lodz accords of February 1981 merely a restatement of powers which the universities already possessed but had not used.

With martial law, the reforms were cancelled and university life reverted to the statutes of 1958, which place full administrative power in the hands of the rector and reduce university senates and faculty councils to a merely consultative role. Many features of the pre-Lodz syllabuses, including compulsory Russian, have been restored.

How far the proposed new law will embody these "temporary" measures is not clear. As early as last summer, the then minister, Dr Jerzy Nawrocki, tried to 